\title{
A STUDY TO ASSESS THE EFFECTIVENESS OF A STRUCTURED TEACHING PROGRAMMEME ON KNOWLEDGE REGARDING ILL EFFECTS OF ALCOHOL CONSUMPTION AMONG NURSING STUDENTS STUDYING IN SELECTED COLLEGE OF NURSING, AJMER
}

\section{Jaindra Narolia}

M.Sc. Nursing, Govt. College of Nursing Ajmer

Corresponding Email: jaindra30@gmail.com

\section{ABSTRACT}

Introduction: Alcohol is a group of substances; the technical name of alcohol beverage is ethanol or ethyl alcohol, popularly known as alcohol (James). It was present even in early period in the form of soma, sura, and kalika. It was used to get confidence, courage and faith during the periods of Sutra, Gupta, post Gupta, Mughal and British. ${ }^{1}$

Material \& Methods: The research approach for this study was quantitative approach. A preexperimental design, one group pre-test and post-test was chosen for this study. Target population- nursing students. The study was conducted at selected Nursing college of Aimer. The study was conducted at selected Nursing college of Aimer. Sample size- 60 nursing students. the samples were selected by convenient sampling technique. The self structure knowledge questionnaire was used as a tool to assess the knowledge regarding ill effects of alcohol of nursing students.

Results: reveals the most of pre test 31(51.7\%) had Poor knowledge score, 11 (18.3\%) had Average knowledge score, and 18 (30\%) had Good knowledge score

Conclusion: The results revealed that majority $46.7 \%$ of the respondent had good knowledge with regarding too ill effects of alcohol

Keyword: Assess Effectiveness Ill Effects of Alcohol.

\section{INTRODUCTION}

The term "alcoholism" was first used by the physician Magnus Huss (1849) to describe the systematic adverse effects of alcohol. Alphone Jacob (2003) defined alcoholism as "the use of alcoholic beverages to the point of causing damage to the individual, society or both.",

Alcoholism is a worldwide problem not confined either to developed or to developing nations. The adverse consequences of alcohol not only affect the individual uses, but the society as a whole. The pattern of alcohol intake around the world is constantly evolving and alcohol is present today

The WHO estimates that about 140 million people throughout the world suffer from alcohol dependence. Archives of General Psychiatric reported that 
approximately $30 \%$ of Americans suffered from alcohol consumed disorders, including $17.8 \%$ with alcohol abuse and $12.5 \%$ with alcohol dependence. ${ }^{3}$

Rupesh Kumar et al. (2015) conducted a study on An epidemiology study on alcohol consumption and knowledge of its on harmful effects on human among rural adult population of adopted village covered under field practice are of a private medical college in Udaipur Rajasthan. In this study sample 400 subjects and data collected through the random sampling technique with the cross sectional study approach used. Result was found that $47.25 \%$ adult consumed alcohol and no adequate knowledge regarding alcohol consumption ${ }^{4}$ Randolph Me et al. (2009) conducted a comparative study to assess the role of gender and ethnicity in the relationship between alcohol use and risky sexual behavior among 425 college students. The findings indicated that the African-American women reported less drinking and less positive alcohol expectancies than the other women. Older men engaged more often than the younger in drinking and reported more sexual partners. Younger age and greater perceived risk for HIV were positively associated with condom use for both men and women. ${ }^{5}$

\section{OBJECTIVES}

1. To assess the existing knowledge of nursing students regarding ill effects of alcohol consumption

2. To administer STP regarding ill effects of alcohol consumption

3. To assess the post test knowledge score after administering STP.

4. To determine difference between mean pre test knowledge score and mean post test knowledge score.

5. To find out association between pre test knowledge score and selected demographic variables.

\section{MATERIAL \& METHODS:}

RESEARCH APPROACH: The research approach for this study was quantitative approach

RESEARCH DESIGN: A preexperimental design, one group pre-test and post-test was chosen for this study.

POPULATION: Target population- nursing students

SETTING OF THE STUDY: The study was conducted at selected Nursing college of Aimer

1. For main study -RR college of Nursing Ajmer

2. For pilot study- Mittal college of

Nursing Ajmer 


\section{SAMPLE AND SAMPLING}

TECHNIQUE: Sample size- 60 nursing

students. The samples were selected by

convenient sampling technique.

\section{DATA COLLECTION TOOOLS AND}

\section{TECHNIQUES}

The research tool was developed in English \& Hindi language after extensive review of literature and expert opinion. The self structure knowledge questionnaire was used as a tool to assess the knowledge regarding ill effects of alcohol of nursing students.

\section{DESCRIPTION OF THE TOOL:}

The instrument consists of two parts.

PART-I: Consists of demographic variables age, gender, religion, residential area, type of family, father occupation, monthly income of family, sources of information regarding alcohol abuse and other.

PART-II: The structured knowledge questionnaire consists of 24 multiple choice questions to assess the effectiveness of structure teaching programme on knowledge regarding ill effects of alcohol consumption.

RESULT: SECTION I Analysis and interpretation of pre test and post test knowledge score of nursing students the participants

\begin{tabular}{|c|c|c|c|c|}
\hline \multicolumn{5}{|c|}{$\begin{array}{l}\text { distribution of pre } \& \text { post test } \\
\text { knowledge score } \\
N=60\end{array}$} \\
\hline & \multicolumn{2}{|c|}{ Pre level } & \multicolumn{2}{|l|}{ Post level } \\
\hline $\begin{array}{l}\text { Level of } \\
\text { knowledge }\end{array}$ & $\begin{array}{c}\text { Freque } \\
\text { ncy }\end{array}$ & $\begin{array}{c}\text { Percent } \\
\text { age }\end{array}$ & Frequency & Percentage \\
\hline Poor $<50 \%$ & 31 & 51.7 & 18 & 30.0 \\
\hline $\begin{array}{l}\text { Average } \\
51-69 \%\end{array}$ & 11 & 18.3 & 14 & 23.3 \\
\hline $\begin{array}{l}\text { Excellent }>7 \\
0 \%\end{array}$ & 18 & 30.0 & 28 & 46.7 \\
\hline Total & 60 & 100.0 & 60 & 100.0 \\
\hline
\end{tabular}

SECTION III: Aspect wise Mean, SD and Mean\% of pre test \& post test knowledge score

Table-2 Aspect wise mean, SD and mean\% of pre and post test knowledge score. 
SDES-International Journal of Interdisciplinary Research

(Peer Reviewed Refereed Journal)

Crossref DOI: 10.47997/SDES-IJIR/1.2.2020.29-82

ISSN (O): 2582:7162

https://shreedadueducational.com/journal

\begin{tabular}{|c|c|c|c|c|c|c|c|c|c|c|}
\hline & & \multicolumn{3}{|c|}{ Mean X Pre } & \multicolumn{3}{|c|}{ Mean Y post } & \multicolumn{3}{|c|}{$(\mathrm{XY})$} \\
\hline & $\begin{array}{l}\mathrm{Ma} \\
\mathrm{rks}\end{array}$ & $\begin{array}{l}\text { M } \\
\text { ea } \\
n\end{array}$ & $\begin{array}{l}\text { Std. } \\
\text { Devia } \\
\text { tion }\end{array}$ & M\% & $\begin{array}{l}\text { Mea } \\
\text { n Y }\end{array}$ & S.D & $\begin{array}{l}\mathrm{Me} \\
\mathrm{an} \\
\%\end{array}$ & $\begin{array}{l}\mathrm{Me} \\
\text { an }\end{array}$ & S.D & $\begin{array}{l}\text { Mea } \\
\text { n } \\
\%\end{array}$ \\
\hline $\begin{array}{l}\text { Physical } \\
\text { effects }\end{array}$ & 9 & $\begin{array}{l}4 . \\
5 \\
8\end{array}$ & $\begin{array}{l}1.6 \\
19\end{array}$ & $\begin{array}{l}50.8 \\
8\end{array}$ & 7.62 & 1.354 & $\begin{array}{l}84.6 \\
6\end{array}$ & $\begin{array}{l}3.0 \\
33\end{array}$ & 265 & $\begin{array}{l}33.7 \\
8\end{array}$ \\
\hline $\begin{array}{l}\text { Nutritio } \\
\text { nal } \\
\text { effects }\end{array}$ & 3 & $\begin{array}{l}1 . \\
2 \\
3\end{array}$ & $\begin{array}{l}.78 \\
9\end{array}$ & $\begin{array}{l}41.0 \\
0\end{array}$ & 2.52 & .651 & $\begin{array}{l}84.0 \\
0\end{array}$ & $\begin{array}{l}1.2 \\
83\end{array}$ & .138 & $\begin{array}{l}43.0 \\
0\end{array}$ \\
\hline $\begin{array}{l}\text { Psycholo } \\
\text { gical } \\
\text { effects }\end{array}$ & 2 & .9 & $\begin{array}{l}.72 \\
0\end{array}$ & $\begin{array}{l}46.0 \\
0\end{array}$ & 1.72 & .524 & $\begin{array}{l}86.0 \\
0\end{array}$ & $\begin{array}{l}.80 \\
0\end{array}$ & .196 & $\begin{array}{l}40.0 \\
0\end{array}$ \\
\hline $\begin{array}{l}\text { social } \\
\text { effects }\end{array}$ & 3 & $\begin{array}{l}1 . \\
3 \\
8\end{array}$ & $\begin{array}{l}.88 \\
5\end{array}$ & $\begin{array}{l}46.0 \\
0\end{array}$ & 2.38 & .865 & $\begin{array}{l}79.3 \\
3\end{array}$ & $\begin{array}{l}1.0 \\
00\end{array}$ & .020 & $\begin{array}{l}33.3 \\
3\end{array}$ \\
\hline $\begin{array}{l}\text { Other } \\
\text { effects }\end{array}$ & 7 & $\begin{array}{l}3 . \\
9 \\
2\end{array}$ & $\begin{array}{l}1.4 \\
30\end{array}$ & \begin{tabular}{|l}
56.0 \\
0
\end{tabular} & 5.17 & .806 & $\begin{array}{l}73.8 \\
5\end{array}$ & $\begin{array}{l}1.2 \\
50\end{array}$ & .624 & $\begin{array}{l}17.5 \\
6\end{array}$ \\
\hline Over all & $\begin{array}{l}2 \\
4\end{array}$ & $\begin{array}{l}1 \\
2 . \\
0 \\
3\end{array}$ & $\begin{array}{l}2.8 \\
52\end{array}$ & $\begin{array}{l}50.1 \\
2\end{array}$ & $\begin{array}{l}20.2 \\
2\end{array}$ & 2.688 & $\begin{array}{l}84.2 \\
5\end{array}$ & $\begin{array}{l}8.1 \\
83\end{array}$ & .164 & $\begin{array}{l}34.1 \\
3\end{array}$ \\
\hline
\end{tabular}

Interpretation-In Table-2 (effectiveness) it is depicted that aspect wise mean of Questions related to Physical effects was 3.033, standard deviation 0.256 and mean \% score 33.78, Questions related to knowledge of Nutritional effects of mean score was 1.283, standard deviation 0.138 and mean $\%$ 43.00, Psychological effects of mean score was .800 , standard deviation .020 and mean \% 40.00, social effects of mean score was 1.000, standard deviation and mean \% 33.33, social effects of mean score was 1.250, standard deviation .624 and mean \% 17.56 and social effects of mean score was
8.183, standard deviation .164 and mean \% 34.13

\section{SECTION=IV}

Comparison between pre test and post test knowledge score of nursing students regarding ill effects of alcohol consumption

Table 3 Comparison between pre test and post test knowledge score on ill effects of alcohol consumption

\begin{tabular}{|c|c|c|c|c|c|c|c|}
\hline & & Mean & $\begin{array}{l}\text { Std. } \\
\text { Deviatio } \\
\text { n }\end{array}$ & $\begin{array}{l}\text { Std. } \\
\text { Error } \\
\text { Mean }\end{array}$ & M.D & $t$-test & \\
\hline \multirow{2}{*}{$\begin{array}{l}\text { Physical } \\
\text { effects }\end{array}$} & Pre & 4.58 & 1.619 & .209 & \multirow{2}{*}{3.033} & \multirow{2}{*}{11.902} & \multirow{2}{*}{ Sig } \\
\hline & Post & 7.62 & 1.354 & .175 & & & \\
\hline \multirow{2}{*}{$\begin{array}{l}\text { Nutrition } \\
\text { al effects }\end{array}$} & Pre & 1.23 & .789 & .102 & \multirow{2}{*}{1.283} & \multirow{2}{*}{10.010} & \multirow{2}{*}{ Sig } \\
\hline & Post & 2.52 & .651 & .084 & & & \\
\hline \multirow{2}{*}{$\begin{array}{l}\text { Psycholo } \\
\text { gical } \\
\text { effects }\end{array}$} & Pre & .92 & .720 & .093 & \multirow{2}{*}{.800} & \multirow{2}{*}{7.049} & \multirow{2}{*}{ Sig } \\
\hline & Post & 1.72 & .524 & .068 & & & \\
\hline \multirow{2}{*}{$\begin{array}{l}\text { social } \\
\text { effects }\end{array}$} & Pre & 1.38 & .885 & .114 & \multirow{2}{*}{1.000} & \multirow{2}{*}{7.215} & \multirow{2}{*}{ Sig } \\
\hline & Post & 2.38 & .865 & .112 & & & \\
\hline \multirow{2}{*}{$\begin{array}{l}\text { Other } \\
\text { effects }\end{array}$} & Pre & 3.92 & 1.430 & .185 & \multirow{2}{*}{1.250} & \multirow{2}{*}{5.893} & \multirow{2}{*}{ Sig } \\
\hline & Post & 5.17 & .806 & .104 & & & \\
\hline \multirow{2}{*}{$\begin{array}{l}\text { Pre test } \\
\text { and post } \\
\text { test }\end{array}$} & Pre & 12.03 & 2.852 & .368 & \multirow{2}{*}{8.183} & \multirow{2}{*}{17.839} & \multirow{2}{*}{ Sig } \\
\hline & Post & $\begin{array}{l}20.2 \\
2\end{array}$ & 2.688 & .347 & & & \\
\hline
\end{tabular}

Table 3 Pre and post Mean difference of nursing students According to their knowledge table which indicates that mean \& S.D of Pre vs. Post of Knowledge of dimension of Physical effects on Ill effects of alcohol consumption among nursing 
students studying in selected Nursing college of Ajmer i.e. pre group are $4.58 \pm 1.619$, post are $7.62 \pm 1.3354$. As per the table the mean difference of pre vs. post group nursing students selected nursing college (3.033) and the t-ratio was statistically significant as the obtained value (11.902) is higher than the tabulated value (2.00) required for t-ratio to be significant at .05 level of confidence.

\section{CONCLUSION}

On the basis of findings of the study the following conclusions were made:

$>$ The results revealed that majority $46.7 \%$ of the respondent had good knowledge with regarding too ill effects of alcohol

$>$ The subjects have expressed that they have been enabled to practice the knowledge in their present ill effects alcohol consumption Hence the developed structure teaching programme on ill effects of alcohol consumption among nursing students was instructionally effective, appropriate and feasible

\section{RECOMMEDATION}

$>$ A similar study can be conducted on larger sample to generalized findings

A A similar study can be conducted with control group for effective comparison

A comparative study can be conducted to assess the knowledge level of nursing college students and other grades of college students.

\section{REFERENCES}

1. Dr. Alan De Sousa, Dr. Dhanalakshmi De Sousa, Dr. Avinash De Sousa, Psychiatry in Asia $1^{\text {st }}$ edi. Vikas Medical Publishers, Mumbai; 2005. Page No.105

2. K.P. Neeraja, Essentials of Mental Health and Psychiatric Nursing, $1^{\text {st }}$ edi, Jaypee Brothers Medical Publishers; 2008. Page No.593

3. Ganesan E. Alcohol Behaviour and Spirituality Among Alcoholics. The Nurse International. 2009 June-July; 1 (1) $: 10-13$

4. Mrs. Vanitha. S, A study to Assess The Knowledge and Attitude Towards Alcoholism Among Adolescent School Children. Indian Journal of Holistic Nursing. 2009 March; 4 (4) : 33-35

5. Randolph Me, Torres H, Gore - Felton C, Lloyd 13, Mc Garvey EL. Alcohol use and sexual risk behaviour among college students: understanding gender and ethnic differences. Am J Drug Alcohol Abuse. 2011; 35 (2) : $80-4$ 